\title{
The Arts Learning through Straw Media in Early Childhood
}

\author{
Azwarna $^{1}$ and Farida Mayar ${ }^{2}$ \\ Early Childhood Department, Padang State University, Padang, Indonesia, azwarnasukriadi@gmail.com \\ Early Childhood Department, Padang State University, Padang, Indonesia, mayarfarida@gmail.com
}

\begin{abstract}
Writing aims to outline the theoretical learning through the arts of natural materials in early childhood. Based on the theory of residual materials and theory of art education in early childhood. The media serve as a natural ingredient in learning to stimulate and excite aspects of child development, because in developing the art of children to acquire the necessary artistic value in the process of growth. In essence, the arts contribute to the orderly learning basic abilities early childhood as well as develop a creative attitude and makes the children can take advantage of the natural ingredients in the environment. With the art of learning through the medium of natural ingredients, more focused children in the use of materials that are not useful into goods that is worth the price.
\end{abstract}

Keywords: Learning the arts, media, natural materials, early childhood.

\section{INTRODUCTION}

Early childhood education is the foundation stone of the first and foremost in to cultivate the child's personality and all aspects of child development in terms of cognitive, language, motor, social, emotional, and art. At this time, it is very good for children to receive an education that is more appropriate, in order to further the development of children to be better. Preschool is the initial momentum to efforts intensive coaching, systematic, and professional. Preschool age is the age that determine the further growth and development.

Early childhood education aims to develop the potential of children optimally. Suyadi (2014: 24) says that the purpose of early childhood education is to give stimulation for the children's potential development to become a man of faith and piety to God Almighty, noble character, healthy, knowledgeable, skilled, critical, creative, innovative, independent, confidence, and become citizens of a democratic and responsible.

The principles in early childhood education is oriented to the needs of children, learning through play, a conducive environment, using integrated learning, develop a variety of life skills, using a variety of media educational and learning resources, implemented gradually and repeatedly, active, creative, innovative, effective, and fun, and use information technology.

According to Suryana (2013) early childhood characteristics, namely: 1) the child is self-centered, 2) children have a curiosity, 3) the child is unique, 4) rich children's imagination and fantasy, 5) the child has a short attention span. Early childhood has characteristics that children see the world from the standpoint of its own interests and the child and believes that the world is filled with things interesting and amazing that encourages a high curiosity in children. Moreover, the uniqueness owned by each child according to their interests, abilities and cultural backgrounds and life are different from one another. Kids have their own distinct world with a person above the age, they are attracted to things that are imaginative so they are rich with fantasy in general.

\section{Early childhood education programs}

Suryana (2017) said that the kindergarten into formal institutions that serve children aged four to six years with the aim to develop every aspect of the development of a wholly owned subsidiary through learning activities fun. Services every child's development made by educators and education personnel. Educators as a teacher is responsible for the development of the child in school.

An educator should be able to encourage and inspire students are able to understand, implement, and develop ways of thinking rationally and objectively in response to the substance or learning materials. According to Suryana (2017: 70) defined learning objectives in a simple and clear, yet attractive presentation system.

Suyadin and Maulidya (2013) states the purpose of early childhood education is to give stimulation to the children's potential development to be human faith and devoted to God Almighty, noble, knowledgeable, skilled, critical, creative, innovative, independent, confident and become citizens of a democratic and responsible.

Early Childhood Education is an attempt aim to the children from the birth until the age of six through education stimulus award therefore the children can grow and develop properly then they can do any development tasks related to their development tasks. 
Suyadi dan Maulidya state (2013: 17-18) early chilhood education is one of the implementation of that focused on laying the foundation toward growth and development, motoric coordination (soft and rough), emotional intelligence, multiple intelligence (multiple intelligences) and spiritual intelligence.

According to Sudarna (2014: 1) early childhood education is aimed to children from early chilhood tah can be done by giving education to help the growth of physical and mind development to prepare the children to enter the early education and the next steps of life.

Trianto (2011: 24) explains that early childhood education is one effort to educate aimed to the child from the birth until the age of six that can be done through granting educational stimulus to help the growth and development of the children to make the children get ready to enter the next educatinal level.

According to Suryana (2016: 25) early childhood education is to provide guidance to children from birth to age six is provided for educational stimulus to help the growth and development of children physically and mentally in order to have the readiness to enter further education.

Meanwhile, according to Mulyasa (2012: 43) early childhood education, the most important base in the personal development of children, both with regard to the character, physical ability, cognitive, language, art, social, emotional, spiritual, self-discipline, self-concept, and self-reliance. Therefore, the provision of education to children stimuli we must first know how the characteristics of children and how children learn and play.

Mansur (2014: 88) states education Early Childhood is the process of fostering growth and development of children from birth to six years is comprehensive covering all aspects of child development, namely: the physical aspect and nonphysical, to provide a stimulus for the development of physical and mental health for all aspects of child development to develop optimally.

\section{Early childhood}

Early childhood is a figure that is undergoing a process of growth and rapid growth for the next life. At this age a child should be given a wide range of stimulation for all aspects of development in order to grow optimally. Early childhood greatly affect further growth and development of children, for the children form a line with what is expected.

Mulyani (2016: 19) is a private early childhood that has a character that is "unique". The unique character of make the adult be entertained, amazed and entertained if they see behavior that is funny and made laugh. Parents also makes his son and daughter a separate entertainment, after a very busy routine and tiring.

According Sudarna (2014: 1) early childhood is a peoses fostering growth and development of children from birth to 6 years, which is comprehensive, covering all aspects of development by providing stimulation and provide coaching education to assist the growth and development of the physical and spiritual so that children have readiness in entering further education.

According Mulyasa (2012: 16): Early childhood is the individual who is undergoing a process of growth and development is very rapid, even said to be a leap of development. Early childhood age range is very valuable compared the next ages for the development of intelligence is extraordinary. Age is a unique phase of life, and are in the process of change in the form of future growth, development, maturation and refinement, both physical and spiritual aspects that lasts a lifetime, gradually, and continiously.

Suryana (2013: 25) states that early childhood is the initial period of the most important and most fundamental throughout the range of human growth and development. Early childhood has unique characteristics because they are in the process of child development subsequent to the end of its development.

Theo and Martin in Suryana (2011) things that are important in the early years of early childhood, among others: (1) 3-year-old son was able to learn to play and talk; (2) children aged 3 to 4 years had a great curiosity, because of the freedom and the opportunity to observe, move and carry out exploration activities themselves and the environment should be given; (3) children aged 2 to 6 years old was delighted to recognize himself and the world that surrounds it. Because it introduces the names of objects in the house, in the yard, at school, it is appropriate at this age; (4) the child's character is formed through the activities and learn over a period of 3-6 years of age, the child moves on and often follow impulses, at this time a good time to develop a child's character.

Art

In early childhood learning, art can serve as a tool to play, it is based on the opinions Kadir (1973: 2), "that children at once artful play, so that children feel happy because of all the turmoil poured his soul". The process is expected to be more creative children, using art as a medium for the development of creativity, so it can be said that art also serves to develop talent, "Art is a way to Become a creative person" (Linderman \& Herberholz, 1979). Benefits of Art Education for children as proposed by Soehardjo (1977: 13). "Art helps the growth and development of children, foster aesthetic, help enhance the growth the life. Increasing physical, mental, estetika. Educated creative imagination,

Media

The media is very important in implementing the learning, because the media is one tool conveys the material to learners. According to Daryanto (2010: 6) states instructional media is anything that can be used to deliver the message (study materials), so as to stimulate attention, interests, thoughts, and feelings of children in learning activities to achieve the learning objectives.

Benefits of media in learning is as follows: the delivery of learning material can be made uniform, the learning process becomes more interesting, learning becomes more interactive, the amount of time learning can be reduced, the quality of student learning can be improved, the learning process can happen anywhere and anytime, positive attitude students to the learning process can be improved, as well as the teacher's role may change to a more positive and productive.

Media that can be used from the natural environment around the child, such as: water, sand, soil, bamboo, seeds, stem, dry leaves, stones, wood, and others. Therefore, 
teachers are required to be creative in the process of natural media to be media interactive learning for children.

Natural materials are materials obtained directly from nature ". Natural ingredients are obtained from natural materials to create a product or works. Natural materials can be utilized in the study. According Chayat in Yukananda (2012: 2) "natural materials that can be used include: rocks, wood and twigs, seeds, leaves, stem, bamboo, etc.

One of the natural ingredients media that can be used as a useful GCC namely rice straw. Rice straw can be used as a wide variety of useful items such as flowers, wall hangings, a pencil holder, photo frame and so on. This craft can be an alternative attempt to process natural materials into goods that can be utilized. Manufacture of straw craft media are by rolling, sticking and cutting the straw therefore into something useful.

\section{DISCUSSION}

According to Mulyasa (2012: 16) Early childhood is the individual who is undergoing a process of growth and development is very rapid, even said to be a leap of development. Early childhood age range is very valuable than later ages because of the development of intelligence is extraordinary. Furthermore, according to Trianto (2011: 14) early childhood is a unique individual and has its own characteristics according to the stages of his age. 0-6 years early childhood was the golden era (golden age) in which stimulation of the entire individual aspects who are undergoing a process of rapid and fundamental developments for the next life. At this time the development process plays an important role for the task of further developments.

Learning the art is two-dimensional art work activity that is intended to produce or reproduce a work of art with the help of the tool / reference a particular print. Meanwhile, according Pamadhi (2015: 4.4) printing can be done in a way that is very simple to very complicated way. As for ways to do a simple print on media that can be found all around us. The importance of developing the abi ladies through print art is able to develop creativity and imagination in children as well as children can adjust to the school environment. According to Lerin (2009) benefit from printing activities is to develop the creativity of children, can enhance children's ability to combine colors.

Miarso in Fadlillah (2012: 206) states that the so-called learning media is everything that is used to deliver messages and to stimulate thoughts, feelings, concerns, and willingness of the learners so as to encourage the process of learning the deliberate, purposeful, and controlled. According to Kemp and Dayton in Fadlillah (2012: 207) the benefits of media in learning is as follows: the delivery of learning material can be made uniform, the learning process becomes more interesting, learning becomes more interactive, the amount of time learning can be reduced, the quality of student learning can be improved, the learning process can happen anywhere and anytime, positive attitude of students towards the learning process can be improved, as well as the teacher's role may change to a more positive and productive.

Latif, et al (2013: 165-166) suggests that the benefits of learning media is: a) Book / learning information can be conveyed more clearly, interesting, concrete and not only in the form of words written or spoken sheer; b) Overcoming the limitations of space, time, and power the senses; c) Increase the active attitude of students in learning; d) Generate excitement and motivation in learning; e) Allows a more direct interaction between students in the environment and reality; f) Allows students to learn on their own according to their ability and interest; g) Providing stimulants, experiences, and perceptions of the same for students.

Based on some of the above opinion can be concluded that the learning media is very useful as a support in the learning process increasing. Learning media can provide direct learning experiences and more concrete to the child.

According to Fadlillah (2012: 211-212) a variety of media for early childhood learning can be classified into three, namely: a) Media Audio, is a learning medium containing messages in auditory form, $b$ ) visual media, is the only media relying on the sense of sight, c) audiovisual media, is a media that has elements of sound and image elements.

Meanwhile, according to Latif, et al (2013: 152), among other types of media: (1) Media visual / graphic media is media that only can be seen. Such as drawings, sketches, diagrams, charts / charts, cartoons, etc; (2) Media Audio is a medium associated with the senses of hearing such as radio, magnetic tape recorders etc; (3) Media projection of silent / audio-visual media is related to hearing and vision such as television, video, and film.

Of the few opinions on the above it can be concluded that the types of instructional media including audio media, visual media and audio-visual media. Visual media is divided over a still image media, the environment, such as soil, plants, animals, water, which can be processed, sold in the market, and the results can be used to meet human needs every day. So the child is also equipped with life skills.

Furthermore, according to Sudjana in Yukananda (2012: 2) states that "natural ingredients that materials obtained directly from nature". Natural ingredients are obtained from natural materials to create a product or works. Natural materials can be utilized in the study. According Chayat in Yukananda (2012: 2) "natural materials that can be used include: rocks, wood and twigs, seeds, leaves, stem, bamboo, and so forth".

Opinions can be concluded that the media is a tool of natural ingredients and materials used in learning to convey the purpose of learning from the teacher to the child obtained from natural environtment around.

The media type can be obtained from nature is water, sand, soil, rocks, wood, and others. According Sudjana \& Rival (2010: 213) of the natural environment with respect to everything that naturally as the geographical situation, climate, temperature, season, rainfall, flora, fauna, natural resources (land, water, forests, rocks and etc).

Based on the above opinion can be concluded that many media that can be used from the natural environment around the child, such as: water, sand, soil, bamboo, seeds, stem, dry leaves, stones, wood, and others. Therefore, teachers are required to be creative in the process of natural media to be media interactive learning for children. 
Straw is a byproduct of farming in the form of stalks and stems of cereal crops that have been dried, after the seeds grains are separated. According Rubiyar (2006: 17) straw is one of the agricultural waste, utilization is still not optimal. During this time the rice straw used as animal feed. In some areas this material has been used as a growing medium for mushrooms straw. Nonetheless, it is still highly abundant material that sometimes have to be burned.

Furthermore, according to Kurniasari, et al (2008: 60) is the rice straw that had taken its (peel) so stay stems and leaves which is the largest agricultural waste and has not been fully exploited because of their technical and economic factors. According to Indonesian dictionary paddy straw is the stem is dry (the rice has been harvested) rice straw can be used as a wide variety of useful items such as flowers, wall hangings, a pencil holder, photo frame and so on. This craft can be an alternative attempt to process natural materials into goods that can be utilized. Manufacture of straw craft media are by rolling, sticking and cutting the straw therefore into something useful.

Opinions can be concluded that straw is a natural material that can be processed into useful items through choose, stick, and cut so as to develop fine motor skills of children

Overview Learning Through Art Media Natural Ingredients in Early Childhood

The media is very important in implementing the learning, because the media is one tool conveys the material to learners. Rice straw can be used as a wide variety of useful items such as flowers, wall hangings, a pencil holder, photo frame and so on. This craft can be an alternative attempt to process natural materials into goods that can be utilized. Manufacture of straw craft media are by rolling, sticking and cutting the straw therefore into something useful.

Before the straw is ready for use as a base for media preparation, preparation needs to be done first. This preparation is modified from the book Rubiyar (2006: 19) to fit the needs of media creation. That preparation including the following:

1. Clean the pipette stem or straw with a knife.

2. Then wash them clean straw.

3. After drying hay net brought the sun to dry.

Equipment and materials used in making hay media is modified from Rubiyar (2006: 21) to suit the needs of media creation. a) The tools used in the media using straw is scissors. b) Materials used in media use straw straw is marked with the length of $12 \mathrm{~cm}$ sufficiently hard cloth that has been in a tubular shape with a size of $10 \times 12 \mathrm{~cm}$. c) Glue (double-sided)

The steps to create a straw-inspired Rubiyar (2006: 4) to fit the needs of media creation. The making steps are as follows: 1) provides the tools and materials needed in the use of media jerami.2) choose straw match the colors diinginkannya.3) attached straw that has been cut on the surface of hardware cloth using glue. 3) develop hay that has been on the outboard until all closed sempurna.4) smoothed straw that has been affixed by cutting the tip to the surface at rata.5). Then, to decorate the outside of the child wrapped straw at the top, middle and bottom, and garnished with dried flowers.

\section{CONCLUSION}

Media that can be used from the natural environment around the child, such as: water, sand, soil, bamboo, seeds, stem, dry leaves, stones, wood, and others. Therefore, teachers are required to be creative in the process of natural media to be media interactive learning for children.

Natural materials are materials obtained directly from nature ". Natural ingredients are obtained from natural materials to create a product or works. Natural materials can be utilized in the study. According Chayat in Yukananda (2012: 2) "natural materials that can be used include: rocks, wood and twigs, seeds, leaves, stem, bamboo, etc.

One of the natural ingredients media that can be used as a useful GCC namely rice straw. Rice straw can be used as a wide variety of useful items such as flowers, wall hangings, a pencil holder, photo frame and so on. This craft can be an alternative attempt to process natural materials into goods that can be utilized. Manufacture of straw craft media are by rolling, sticking and cutting the straw therefore into something useful.

\section{REFERENCES}

1) Suyadi dan Maulidya Ulfah. 2013. Konsep Dasar PAUD. Bandung: PT Remaja Rosdakarya.

2) Latif, dkk. 2013. Orientasi Baru Pendidikan Anak Usia Dini. Jakarta: Kencana.

3) Triharso, Agung. 2013. Permainan Kreatif \& Edukatif Untuk Anak Usia Dini. Yogyakarta: Penerbit Andi.

4) Rubiyar. 2006. Kerajinan dari Jerami. Surabaya: Tiara Aksa Trubus Agrisarana.

5) Sudjana, Nana, dan Ahmad Rivai. 2013. Media Pengajaran. Bandung: Sinar Baru Algesindo.

6) Fadlillah, Muhammad. 2012. Desain Pembelajaran Pendidikan Anak Usia Dini. Yogyakarta: Ar-Ruzz Media.

7) Sujiono. 2010. Bermain Kraetif Berbasis Kecerdasan Jamak. Jakarta: PT. indeks.

8) Suryana, Dadan. 2017. Pengetahuan Tentang Strategi Pembelajaran, Sikap dan Motivasi Guru. Fakultas Ilmu Pendidikan Universitas Negeri Padang.

9) Suryana, dadan. 2017. Pembelajaran Tematik Terpadu Berbasis Pendekatan Saintifik di Taman Kanak-kanak. Jurnal Pendidikan Usia Dini Volume 11 Edisi 1, April 2017

10) Suyadi dan Ulfah, Maulidya. 2013. Konsep Dasar Paud. Bandung: PT Remaja Rosdakarya. 
11)Trianto, 2011. Model Pembelajaran Terpadu Konsep,Strategi Dan Implementasinya Dalam Kurikulum Tingkat Satuan Pendidikan (KTSP), Jakarta : Bumi Aksara.

12) Mulyasa, E. 2012. Manajemen PAUD. Bandung: Remaja Rosdakarya Offset.

13) Mulyani, Novi. 2016. Dasar-dasar Pendidikan Anak Usia Dini. Yogyakarta: Kla Imedia.

14) Sudarna. 2014. Pendidikan anak Usia Dini Berkarakter.Yogyakarta:Genius.

15)Jamaris, Martini. 2006. Perkembangan dan Pengembangan Anak Usia Taman Kanak-kanak. Jakarta: Gramedia. 